\title{
THE RIGHT OF PERSONS EMPLOYED IN POLISH PUBLIC SERVICES TO ASSOCIATION IN TRADE UNIONS
}

\begin{abstract}
The article aims at presenting the reconsidered model of association of public servants under the Polish legal system. In the past, there was a statutory imposed limiting monism in the trade union movement of military services officers. Since 2019 trade union pluralism has been introduced for the Police, Border Guard, and Prison Service officers, which is analyzed in the paper. Another issue discussed in this article is the right of association of persons employed in civil public administration.
\end{abstract}

Słowa kluczowe: związek zawodowy, służby mundurowe, straż graniczna, policja, służba więzienna

Keywords: trade union, public services, Border Guard, Police, Prison Service

ASJC: 3308, JEL: K31

On 19 July 2019, the Parliament of the Republic of Poland adopted the Act extending the right of officers of the Police, Border Guard and Prison Services to form and join trade unions (Dz.U. 2019, item 1608). The newly adopted regulation is an inspiration to reconsider the model of association of public servants under the Polish legal system. The term "public servants" or "those employed in public services" refers not only to those employed in widely understood public administration, but also those serving in military services.

The starting point for further discussion will be the statement that persons who are employed in Polish public service structures perform work under various legal regimes, starting from labour law, through civil law to administrative law. As far as employment under labour law is concerned, the basis for performing work in public services may be both the employment contract and the appointment or nomination. In practice, they are highly differentiated, although appointment and nomination apply to persons in managerial positions. Sometimes, public services also employ workers pursuant to civil law contracts, in particular the contract of mandate. Such persons perform auxiliary work and never hold managerial positions.

Additionally, certain employees in Polish public services are employed under administrative law. This applies, in particular, to the officers of the Police, Border Guard, 
Prison Service, the Internal Security Agency, the Office of State Protection and the soldiers of the armed forces of the Republic of Poland. Employment in these services is characterised by being strongly subordinated to one's superiors, and the employment conditions are, generally, defined in the relevant acts of law (Kuczyński 2015, p. 391). These public servants enjoy certain special rights, which may sometimes resemble privileges, as compensation for their increased availability to work. Currently, this category of workers also includes prosecutors (Baran 2017, pp. $469 \mathrm{ff}$ ). In the Polish judiciary, judges have a separate status. It applies both to those who adjudge in common courts and to judges of administrative courts or of the Supreme Court.

Art. 12 and 59 of the Constitution of the Republic of Poland guarantee the freedom of association in trade unions. In its subjective dimension, it is specified in the doctrine of employment as the right of association (Sanetra 1997, pp. 2 ff; Baran 2001, pp. $53 \mathrm{ff}$ ). It is particularly strongly differentiated in the widely understood public service. Based on the model approach, one may distinguish three normative solutions:

1. full right of association consisting in the right to form and join trade unions,

2. limited right of association consisting only in the right to join an existing trade union, and

3. deprivation of the right of association as a result of a statutory ban on joining trade unions.

Let me start the analyses of this issue with looking at the status of military services until the 26 October 2019 (Sękara 2003-2004, pp. 268 ff). Until that day, officers employed in military services on administrative law basis had either a limited right of association or they were completely deprived of this right. As far as the first group is concerned, it included police officers, as well as officers of the Prison Service and the Border Guard. They could be associated only in one, sector trade union (Baran 2002, p. 121) (e.g. the Independent, Self-Governing Trade Union of Police Officers). Thus, under the Polish legal system, we dealt with a statutory imposed limiting monism in the trade union movement. The legal situation changed after the introduction of the Act of 19 July 2019 amending the Act on the Police, the Border Guard and the Act on Prison Service (Dz.U. 2019, item 1608). This act introduced trade union pluralism for the specified three groups of public servants. Thus, de lege lata, they may join all kinds of trade unions, even those that associate civilian employees. Hence, the Act of 19 July 2019, expands their right of association significantly. However, it also introduced certain limitations. This refers to the provision stating that a police officer or an officer of the Prison Service or the Border Guard may be a member of an inter-enterprise trade union whose scope encompasses only organisational units of the Police or of other services. As a result, a special type of a "police" inter-enterprise trade union organisation was introduced to the Polish collective employment law system. In the normative sphere, this undermines the structural and competence-based uniformity of the trade union movement.

The expansion of the trade union pluralism in the structures of the Police, Border Guard and Prison Service was met with disapproval of the trade union organisations 
that existed in these services. Their members point to the fact that trade union pluralism will contribute to the weakening of the negotiating position of the existing trade unions, and that public authorities will be able to apply the policy divida et impera towards several different trade unions. This type of risk seems real in practice. The possibility to enter into particular collective agreements only with specific trade unions may result in the deterioration of the level of security of the professional or social interests of the public servants.

On the other hand, under Polish law, "civilians" employed in the structures of the Police enjoy full right of association. The same also applies to persons employed pursuant to civil law contracts.

Following the previous considerations on the rights of association of officers of military forces in the Polish legal system (Baran 2019, pp. 44-45), it is worth noting that officers of the Internal Security Agency, Intelligence Agency, the Office of State Protection, and the Central Anti-Corruption Bureau are forbidden to join trade unions by virtue of law. In practice, this means that these officers do not have the right to form or join trade unions.

The status of professional soldiers in terms of the right to association is similar ${ }^{1}$. Pursuant to Art. 108 of the Act of 11 September 2003 on the professional military service (Dz.U. 2019, item 330 consolidated text, as amended), soldiers do not have the right to form or join trade unions, either. Their membership in any existing trade unions expires upon the commencement of professional military service. Here, it is worth noting that the lawfulness of the statutory ban on forming or joining trade unions has been confirmed by the jurisprudence of the Constitutional Tribunal (see: judgment of the Constitutional Tribunal of 7 March 2000, K 26/98, OTK 2000, No. 2, item 57).

Analysing the status of widely understood public servants, one should give some thought to those who are employed in the judiciary. As far as judges lege non distinquente are concerned (of all kinds of courts), they are forbidden to join trade unions pursuant to Art. 178, item 3 and Art. 195, item 3 of the Constitution of the Republic of Poland. From the point of view of Art. 1, item 2 of the ILO Convention C151, this solution seems to be defective (Baran 2019, pp. 41-42), as the activities of judges are neither policy-making nor of a highly confidential nature. However, the legal situation of prosecutors employed in common organisational units of the prosecution service is different. Pursuant to Art. $97 \$ 3$ of the Act of 28 January 2016-Prosecution Service Law (Dz.U. 2019, item 740 consolidated text), a prosecutor may be active in organizations for public prosecutors or employees of the public prosecutor's office. Trade unions should also be included in this category of entities. This interpretation is justified by dubio pro libertate argumentation in reference to Art. 59, item 1 of the Constitution of the Republic of Poland. As far as employees of administrative courts and prosecutor's

${ }^{1}$ In terms of the right of association, the status of officers of the Military Counterintelligence and the Military Intelligence services is the same. See: Art. 40, item 2 of the Act of 9 June 2006 on the service of the officers of the Military Counterintelligence and Military Intelligence Services, Dz.U. 2018, item 1516. 
offices are concerned, binding legal regulations do not foresee any limitations of their right of association. As a result, they may join or form all types of trade unions. The same also applies to persons employed in the judicial administration pursuant to civil law contracts.

Another issue that should be discussed here is the right of association of persons employed in civil public administration. As far as the body of widely understood civil servants are concerned, their legal status in this respect is varied. In the light of binding legislation, both self-government employees and members of the civil service may form and join trade unions without any limitations. Thus, they enjoy a full right of association. De lege lata the full right of association is also granted to municipal and communal guards (the Act of 29 August 1997 on Municipal Guards, Dz.U. 2018, item 928). The governing mechanisms are similar as in the case of self-government workers. Employees of the Supreme Chamber of Control also have such right. However, it does not apply to employees who supervise or perform inspection activities, who may only be members of the trade union that associates exclusively employees of the Supreme Chamber of Control. Thus, this structure is characterised by strong organisational monism.

To elaborate on the discussion on the status of civil servants, it is worth noting that Art. 78, item 6 of the Act on Civil Service forbids persons who hold high positions in the structures of civil service to perform functions in trade unions.

It is also worth noting that, pursuant to constitutional standards, the Polish law system also introduced bans on trade union membership for persons who hold high public offices, as they are expected to be independent and impartial. More specifically, this category includes:

- members of the National Council of Radio Broadcasting and Television (Art. 214, item 2 of the Constitution of the Republic of Poland),

- the President of the Supreme Chamber of Control (Art. 205, item 2 of the Constitution of the Republic of Poland),

- the Ombudsman (Art. 227, item 4 of the Constitution of the Republic of Poland),

- President of the National Bank of Poland (Art. 227, item 4 of the Constitution of the Republic of Poland).

Here, it is worth mentioning that, pursuant to the provisions of Art. 14, item 2 of the Act of 29 August 1997 on the National Bank of Poland (Dz.U. 2019, item 1810 consolidated text), the trade union membership of the members of the Monetary Policy Council is suspended by virtue of law for the period of holding the position in the Council, under the penalty of removal from the Council.

In conclusion of this discussion on the right of association in the Polish legislatory system, it should be stated that the scope of this right among those employed in the public sector meets the basic international standards. Additionally, the Act of 19 July 2019 additionally reinforced the element of pluralism in the trade union movement. However, it remains controversial, as it has extended the rights of association of officers of 
the Police, the Prison Service and the Border Guard in normative terms. On the other hand, its consequences may lead to the deterioration of the standards of protection of their professional and social interests.

\section{References}

Baran K. W. (2001) Wolności związkowe i ich gwarancje w systemie ustawodawstwa polskiego, Bydgoszcz-Kraków.

Baran K. W. (2002) Zbiorowe prawo pracy. Komentarz, Kraków.

Baran K. W. (2017) Ogólnoteoretyczna charakterystyka zatrudnienia prokuratora [in:] R. Babińska-Górecka et al., Tendencje rozwojowe indywidualnego i zbiorowego prawa pracy. Ksiega Jubileuszowa Profesora Grzegorza Goździewicza, Toruń.

Baran K. W. (2019) [in:] K. W. Baran (red.), Zbiorowe prawo zatrudnienia. Komentarz, Warszawa. Kuczyński T. (2015) [in:] K. W. Baran (red.), System prawa pracy. Zatrudnienie niepracownicze, t. 7, Warszawa.

Sanetra W. (1997) Prawa (wolności) pracownicze w Konstytucji, "Praca i Zabezpieczenie Społeczne," nr 11.

Sękara M. (2003-2004) Wolność koalicji funkcjonariuszy służb zmilitaryzowanych w świetle prawa polskiego i międzynarodowego, "Studia z Zakresu Prawa Pracy i Polityki Społecznej."

\section{Court sentences}

Judgment of the Constitutional Tribunal of 7 March 2000, K 26/98, OTK 2000, No. 2, item 57.

\section{Legal acts}

The Constitution of the Republic of Poland of 2 April 1997, Dz.U. 1997, No. 78, item 483 as amended.

The Act of 29 August 1997 on Municipal Guards, Dz.U. 2018, item 928.

The Act of 29 August 1997 on the National Bank of Poland, Dz.U. 2019, item 1810 consolidated text.

The Act of 11 September 2003 on the professional military service, Dz.U. 2019, item 330 consolidated text, as amended.

The Act of 9 June 2006 on the service of the officers of the Military Counterintelligence and Military Intelligence Services, Dz.U. 2018, item 1516.

The Act of 28 January 2016-Prosecution Service Law, Dz.U. 2019, item 740 consolidated text. The Act of 19 July 2019 amending the Act on the Police, the Border Guard and the Act on Prison Service, Dz.U. 2019, item 1608. 